\title{
Disorientasi Politik dan Peran Intermediary Kelas Menengah To Pulo: Politik Lokal di Kepulauan Selayar Pasca Orde Baru
}

\begin{abstract}
Abu Bakar·
Abstract

This paper discusses the emergence of social movements To Pulo with the issue of a new government and the development of the New Order. Today, the issue is increasingly disappearing in local political discourse in Kepulauan Selayar. This paper will explore how these things to happen to focus on the political disorientation and why the role of intermediary actors To Pulo weakened middle class. To explain this case, the use of social movement theory perspective of social identity theory and case study research method. The purpose of this paper to describe a social movement To Pulo by answering questions; how To Pulo social movements?; Why did political disorientation inside could be happened?; Why did middle-class intermediary role fizzle?. The conclusion is the disorientation caused by the absence of a strong commitment. And the weak role of the intermediary is caused by internal conflicts To Pulo.
\end{abstract}

\section{Keywords:}

social movements; social identity theory; intermediary actors; identity politics;

local politics; To Pulo in Kepulauan Selayar.

\begin{abstract}
Abstrak
Tulisan ini mendiskusikan tentang munculnya gerakan sosial To Pulo yang mengusung isu pemekaran dan pembangunan pada masa awal pasca Orde Baru. Dewasa ini, isu tersebut semakin menghilang dalam diskursus politik lokal di Kepulauan Selayar. Tulisan ini akan menguraikan bagaimana hal tersebut bisa terjadi dengan fokus kepada pergeseran orientasi politik dan mengapa peran aktor intermediary kelas menengah To Pulo semakain melemah. Untuk menjelaskan kasus ini, digunakan teori gerakan sosial perspektif social identity theory dan metode penelitian case study. Tulisan ini bertujuan menggambarkan gerakan sosial To Pulo dengan menjawab pertanyaan umum; bagaimana gerakan sosial To Pulo? Secara khusus akan menjawab; mengapa terjadi disorientasi politik? Mengapa peran intermediary kelas menengah To Pulo semakin melemah? Kesimpulannya, disorientasi disebabkan karena tidak adanya komitmen yang kuat dan lemahnya peran intermediary disebabkan oleh konflik internal To Pulo.
\end{abstract}

\section{Kata Kunci:}

gerakan sosial; social identity theory; aktor intermediary; politik identitas; politik lokal; To Pulo di Kepulauan Selayar.

\footnotetext{
- Alumni Pascasarjana Ilmu Politik UGM,

Email: aboe.aboe09@gmail.com
} 


\section{Pendahuluan}

Tulisan ini menjelaskan tentang kelas menengah To Pulo(orang pulau), dalam lanskap dinamika politik lokal di Kepulauan Selayar pasca Orde Baru. Munculnya To Pulo dalam panggung politik lokal di Kepulauan Selayar tidak bisa dilepaskan dari proses demokratisasi yang terjadi di Indonesia. Kenyataannya, demokratisasi dengan segala kekurangan dan kelebihannya telah memberikan ruang bagi To Pulo untuk ambil bagian dalam kontestasi politik di tingkat lokal.

ToPulo merupakan istilah yang disematkan kepada masyarakat lima kecamatan yang bermukim di kawasan Taman Nasional Taka Bonerate, yakni Kec. Pasimasunggu, Kec. Pasimasunggu Timur, Kec. Taka Bonerate, Kec. Pasimarannu dan Kec. Pasilambena (selanjutnya di sebut Kepulaun). Sementara orang yang berdomisili di beberapa kecamatan yang berada di daratan utama Pulau Selayar, disebut To Daratan. Sebenarnya kategorisasi identitas antara To Pulo dengan To Daratan bersifat rancu, pada kenyataannya To Daratan pun merupakan penghuni pulau, yakni Pulau Selayar. Namun kategorisasi ini semakin dimantapkan ketika kepentingan antara keduanya bertemu dalam arena kontestasi yang sama. Sekalipun demikian, kategorisasi ini akan tetap dipertahankan sematamata kepentingan analitis.

To Pulo di masa Orde Baru merupakan kelompok marjinal dengan akses pendidikan yang terbatas. Lemahnya sumber daya manusia To Pulo ditambah dengan tidak memadainya pembangunan di wilayah mereka, semakin memperparah keadaan. Hal ini terjadi karena kurangnya To Pulo memegang posisi penting sebagai pengambil kebijakan ditingkat kabupaten. Sehingga dana-dana pembangunan, kurang teralokasikan di wilayah Kepulauan.

Sejak tumbangnya rezim Orde Baru, diaspora To Pulo di Makassar yang bernasib lebih baik dari kebanyakan To Pulo, telah memikirkan masa depan Kepulauan, terutama pemekaran kabupaten. Ini dilakukan lantaran
To Pulo menganggap bahwa pemerintah daerah tidak berpihak terhadap kecamatan yang berada di Kepulauan yang ditandai dengan minimnya pembangunan ${ }^{1}$. Diaspora To Pulo yang berada di Makassar saat itu, tidak hanya kalangan profesional atau pejabat birokrasi yang bertugas di Makassar dan daerah sekitarnya, akan tetapi juga kalangan terdidik seperti mahasiswa. Kelak merekalah yang ikut berperan memantapkan politik aliran (identitas) di Kepulauan Selayar.

Jika di awal visi politik To Pulo adalah pemekaran wilayah, kini pasca memenangkan kontestasi Pemilukada justru upaya ke arah sana semakin kabur. Mahasiswa sebagai kelas terdidik, selanjutnya disebut sebagai kelas menengah, yang diharapkan dapat berkontribusi demi kemajuan Kepulauan dengan memainkan perannya sebagai aktor intermediary, juga mengalami kemunduran. Salah satu indikatornya adalah bahwa nyaris tidak ada isu-isu Kepulauan yang mereka advokasi. Misalnya, kasus bandara Kayuadi yang seyogyanya akan dibangun di Pulau Latondu, dipindahkan ke Pulau Kayuadi. Padahal bandara ini diharapkan dapat mempermudah akses wisatawan yang ingin berkunjung ke Taman Nasional Taka Bonerate (Sindonews.com, 1 Juli 2013).

Dari uraian di atas, tulisan ini bertujuan untuk menggambarkan gerakan sosial To Pulo dengan fokus kepada pertanyaan; bagaimana gerakan sosial To Pulo? Mengapa terjadi disorientasi politik To Pulo? Mengapa peran intermediary kelas menengah To Pulo semakin melemah? Lalu bagaimana peran mereka dalam melanggengkan politik identitas di Kepulauan Selayar pasca Orde Baru? Tulisan ini akan menggunakan pendekatan gerakan sosial perspektif social identity theory (SIT) untuk memahami dinamika politik To Pulo, terutama untuk melacak penyebab disorientasinya.

${ }^{1}$ Wawancara dengan Hasimuddin, Oktober 2012 
Penelitian ini menggunakan metode penelitian studi kasus (case study). Studi kasus dipilih karena penelitian ini berkenaan dengan satu fase spesifik atau memiliki kekhasan tersendiri terkait dengan fenomena kontemporer yang terjadi. Namun setidaknya ada beberapa alasan; Pertama, politik lokal di Kepulauan Selayar berbeda dengan kasuskasus di beberapa daerah di Indonesia, politik perbedaan cenderung meledak dan berakhir pada kekerasan. Sementara di Kepulauan Selayar politik perbedaan berjalan secara damai. Kedua, To Pulo sebagai identitas kolektif bukanlah identitas asali, yang ditarik dari persamaan etnis, melainkan dikonstruksi. Olehnya karenanya, melalui studi kasus dapat dipelajari secara intensif, detail, dan mendalam tentang latar belakang keadaan atau peristiwa secara apa adanya (Aziz, 2008; Yin, 2005). Metode ini diharapkan dapat memberikan gambaran yang luas tentang gerakan sosial dan terjadinya disorientasi politik To Pulo di Kepulauan Selayar.

Supaya tulisan ini sistematis, maka terlebih dahulu akan dipaparkan hasil review dari beberapa literature dan uraian konsep gerakan sosial perspektif SIT. Selanjutnya perjalanan gerakan sosial To Pulo yang dibagi menjadi empat sub;1) menjelaskan kemunculan kesadaran To Pulo; 2) menjelaskan bagaimana mereka memobilisasi identitas ke dalam panggung politik; 3) menjelaskan disorientasi politik To Pulo; 4) dan memudarnya peran intermediary kelas menengah To Pulo.

Sekalipun studi tentang politik lokal di Indonesia sudah banyak dibicarakan, terutama kumpulan artikel yang dibukukan ke dalam Politik Lokal di Indonesia yang diedit oleh Nordholt dan Klinken (2007). Termasuk artikel yang ditulis Taufiq Tanasaldy (2007) sebagai kontributor yang menjelaskan kontestasi etnis di Kalimantan Barat yang berlangsung damai pasca Orde Baru. Perbedaan ini tulisan ini dengan karya Tanasaldy adalah, pertama, sekalipun sama-sama membicarakan politik damai dalam memperjuangkan political interest lewat ruang demokrasi, akan tetapi tulisan ini tidak memusatkan analisis pada etnisitas. To Pulo bukanlah kategorisasi etnis, melainkan kumpulan etnis/suku yang diplot ke dalam identitas berdasarkan kondisi geografisnya. Kedua, selain perbedaan lokus, Kepulauan Selayar tidak memiliki pengalaman konflik kekerasan sekalipun terjadi ketimpangan antara kedua entitas ini. Bagaimanapun juga pengalaman masa lalu ikut menentukan jalannya perubahan sosial politik. Akan tetapi alasan mengapa ketimpangan yang terjadi tidak berkontribusi pada meledaknya kekerasan, sebagaimana daerah-daerah lain di Indonesia pasca Orde Baru, memerlukan penelitian lebih lanjut.

Dinamika politik lokal di Kepulauan Selayar, terutama To Pulo, menarik untuk diteliti karena: Pertama, selain belum adanya penelitian tentang dinamika politik Kepulauan Selayar dan To Pulo, identitas To Pulo ataupun To Daratan selalu dimunculkan ketika keduanya berhadap-hadapan, dan ini mulai menguat pasca Orde Baru. Namun, pasca kontestasi biasanya identitas yang dimobilisasi ini kembali diendapkan. Kedua, pertentangan ini tidak hanya terjadi di ranah pemilukada, tetapi juga merambah ke dunia mahasiswa ketika memperebutkan posisi penting di dalam organisasi, baik organisasi kedaerahan maupun lembaga-lembaga ekstra kampus, yang memiliki cabang di Kepulauan Selayar. Ketiga, pergeseran orientasi politik To Pulo menandakan visi politik mereka belum stabil. Ketika orang To Pulo berhasil menjadi bupati, mimpi-mimpi mereka tentang pemekaran tidak dieksekusi, mereka justru mempersempit peluang untuk mewujudkan tuntutan mereka di masa awal.

\section{Gerakan Sosial Perspektif Social Identity Theory}

Teori gerakan sosial yang berorientasi pada identitas merupakan antitesis dari teori 
gerakan sosial yang berorientasi pada mobilisasi sumber daya the Resource Mobilization Theory (RMT). SIT menekankan pada nonmaterialistis dan ekspresif, sementara diseberangnya, RMT menekankan rasionalitas dan materialisme. Oleh karenanya, SIT menolak reduksionisme, determinasi tesis materialism, dan konsepsi yang berhubungan dengan formasi sosial yang materialistis. SIT menyelidiki dan berkutat pada pertanyaan tentang solidaritas dan integrasi dalam serangkaian tindakan kolektif (Singh, 2010: 144-145). Tindakan kolektif untuk menemukan, memperjuangkan, dan mempertahankan basis identitas hanya bisa dipahami jika solidaritas sebagai prasyarat diciptakan. Maka, identitas tidak dapat dibentuk melalui partisipasi tak langsung atau sistem delegasi dan perwakilan. SIT menekankan peran aktif aktor untuk terlibat secara langsung dalam serangkaian tindakan kolektif. Sebagaimana dikatakan oleh Pizzorno (dalam Singh, 2010:146) bahwa logika formasi identitas kolektif melibatkan partisipasi langsung para aktor dalam aksi kolektif.

Sekalipun SIT masih menerima elemen kunci dalam analisis Marxis, seperti perjuangan, mobilisasi, kesadaran dan solidaritas, tetapi SIT menolak kelas sebagai basis analisis. Bagi SIT, aksi kolektif adalah ekspresi tentang perjuangan sebagai manusia yang utuh, bukan perjuangan atas nama kelas. SIT merupakan salah satu bagian dari paradigma dalam gerakan sosial baru (GSB) yang juga menolak kelas sebagai pusat analisis. Alan Touraine (dalam Singh, 2010: 158) mengemukakan bahwa konflik sosial dewasa ini, sudah jauh dan tidak berurusan dengan masalah-masalah buruh dan ekonomi, karena isunya bukan lagi mode produksi material, melainkan produksi simbolik. Isu demikian akan sulit untuk dipahami dalam perspektif kelas Marxian.

Dalam SIT, faktor determinan terjadinya gerakan sosial ditentukan oleh tiga hal yakni identitas kolektif, solidaritas dan komitmen (Sukmana, 2013: 53). Identitas kolektif merupakan ikatan antara individu dengan kelompok yang bersifat kognitif, moral dan emosional atau gabungan secara keseluruhan. Sebagaimana dikemukakan oleh Polleta dan Jasper (dalam Klinken, 2007: 107), bahwa “... mendefinisikan identitas kolektif sebagai hubungan kognitif, moral, dan emosional individu dengan komunitas, kategori, praktik, atau lembaga yang lebih luas. Identitas merupakan persepsi akan hubungan atau status kebersamaan yang mungkin sekadar dibayangkan dan tidak selalu harus dialami bersama-sama secara langsung, dan identitas ini berbeda dengan identitas pribadi meskipun mungkin merupakan bagian dari identitas pribadi."

Namun pernyataan Polleta dan Jasper tersebut masih perlu dipertanyakan, sejauh mana identitas kolektif dapat hadir dalam masyarakat yang kompleks, misalnya multi etnis. Kasus To Pulo di Kepulauan Selayar misalnya, To Pulo bukanlah entitas yang monokultural akan tetapi masyarakat plural. Mereka terdiri dari beberapa etnis, tapi kenyataannya mereka mampu mengkonstruksi identitas bersama. Pertanyaan yang perlu diajukan adalah bagaimana ikatan emosional dapat hadir ditengah mereka, sementara mereka memiliki asal-usul yang berbeda? Karena itu teori gerakan sosial secara teoretis tidak dapat berdiri sendiri dalam menjelaskan serangkaian aksi yang basisnya identitas, tanpa meminjam konsep lain dari teori-teori sosiologis yang tersedia.

Untuk memahami penciptaan identitas kolektif To Pulo, interaksionis simbolik membuka jalan lewat konsep framing. Framing atau pembingkaian memusatkan perhatian pada peranan usaha menguasai ide-ide dan identitas-identitas baru dalam membentuk gerakan-gerakan sosial. Para organisator gerakan melakukan mobilisasi dengan jalan melukiskan isu-isu untuk para calon peserta gerakan dengan cara memberikan makna bagi mereka (Klinken, 2007: 14). Framing menurut Todd Gitlin adalah strategi bagaimana realitas atau dunia dibentuk dan disederhanakan 
sedemikian rupa, untuk ditampilkan kepada khalayak pembaca (Haryanto, dkk., 2013: 191). Ancaman yang dianggap membahayakan bagi To Pulo, termasuk diskriminasi dan pembangunan yang tidak merata merupakan piranti framing. Karena itu, To Pulo cukup berhasil dalam membingkai identitas kolektif lewat isu-isu keterbelakangan dan kesenjangan pembanguanan.

Terbentuknya identitas kolektif diikuti konsekuensi hadirnya solidaritas sebagai perwujudan dari perasaan senasib. Solidaritas dibutuhkan untuk merekatkan ikatan individu-individu yang terlibat dalam aksi kolektif. Solidaritas merupakan kunci fundamental dalam sebuah gerakan, karena itu pemimpin dalam gerakan sosial diharapkan mampu menggali perasaan solidaritas dari peserta gerakan (Soeharko, 2006: 6). Framing isu merupakan salah satu cara untuk menumbuhkan solidaritas, karena dapat mengusik pengalaman-pengalaman yang sama dirasakan sebagai bagian yang integral bagi komunitas. Di samping solidaritas, yang tidak kalah penting adalah komitmen. Komitmen dapat menentukan berlangsung atau tidaknya sebuah gerakan. Menurut Kanter (dalam Sukmana, 2013: 58), komitmen dapat didefinisikan sebagai proses bagaimana kepentingan individu menjadi terikat dengan pola-pola organisasi sosial, dari perilaku yang dipandang dapat memenuhi kepentingannya, sebagai ekspresi alami dan kebutuhankebutuhan dari orang.

Untuk memahami disorientasi politik To Pulo dalam studi ini, maka SIT memberikan penjelasan tentang determinannya komitmen dalam sebuah gerakan. Sekalipun identitas To Pulo dapat dimobilisasi, akan tetapi dalam perjalanannya mereka dihadapkan pada memudarnya komitmen untuk mewujudkan visi politik awal. Maka dari itu, SIT digunakan untuk memahami dinamika politik To Pulo di Kepulauan Selayar. Melalui SIT, kita dapat memahami bagaimana identitas To Pulo diciptakan, dan bagaimana cara mereka menyolidkannya dalam arena kontestasi.

Kembali kepada masalah teoretis, secara umum SIT berbeda dengan RMT dalam hal fokus analisis antara tidak dan menggunakan nalar dalam aksi kolektif. Akan tetapi SIT tidak bisa mengabaikan bahwa aksi ekspresif yang melibatkan partisipasi langsung para aktor, secara bersamaan telah mendekati penggunaan rasionalitas instrumental strategis RMT. Ketika identitas aktor-aktor kolektif diakui maka dengan sendirinya dapat ditransformasikan menjadi aksi instrumental (Singh, 2010:147). Artinya, aktor-aktor intermediary (instrumen) juga penting dalam memobilisasi dan memperjuangkan kepentingan identitas kolektif. Karena itu, SIT harus bersinggungan dengan aktor intermediary bagaimanapun situasinya, sekalipun para teoretis murni SIT seperti Pizzorno mengabaikannya. Hal ini berkaitan dengan bagaimana solidaritas dapat dikonsolidasikan dan memobilisasi identitas dalam sebuah gerakan jika tidak melibatkan instrumen semacam lembagalembaga canggih (LSM, Paguyuban). Kaitannya dengan aktor instrumental, ada hal yang tidak dapat dipungkiri dalam aksi kolektif bahwa pentingnya agensi atau aktor sebagai penggerak. Sekalipun SIT tidak memasukkannnya sebagai faktor determinan dalam terjadinya gerakan sosial, tapi faktanya kita tetap membutuhkan lembaga-lembaga canggih tersebut.

\section{Gerakan Sosial To Pulo}

\section{Munculnya Kesadaran Kelas Menengah To Pulo: Mimpi Pemekaran dan Pembangunan}

Transformasi sosial tidak bisa lepas dari kelompok yang biasa disebut kelas menengah. Namun penggunaan kata kelas menengah mengundang problema teoretis seputar definisinya yaitu seperti apa kelas menengah dan bagaimana proses kemunculannya. Pada konsep Marxian tentang kelas, kelas menengah tidak masuk dalam segmentasi dari kelas itu sendiri. Marx hanya mengenal 
kelas produksi dan kelas nonproduksi, biasa disebut sebagai proletar dan borjuis. Sentral dari bangunan konsep kelas adalah tentang siapa yang mempunyai penguasaan terhadap alat-alat produksi dan siapa yang tidak. Maka, kelas menengah tidak memiliki tempat dalam diskursus itu.

Sekalipun minat akademis terhadap kelas menengah Indonesia telah lama dibidik oleh beberapa akademisi, terutama tulisan J. A. C. Mackie (1984), Dick (1985), begitupun kumpulan artikel yang dirangkum oleh Tanter dan Young (1993) serta Jaya (1999), sama sekali tidak ada kesepakatan tentang definisi kelas menengah itu sendiri. Pandangan Subianto (1999:19) sepertinya bisa memberikan semacam penekanan atas kekaburan konsep kelas menengah itu sendiri, kekaburan pengertian kelas menengah di Indonesia barangkali karena konsep kelas menengah itu sendiri kurang berakar dalam sejarah politik Indonesia maupun sejarah masyarakat Indonesia". Namun untuk kepentingan studi ini, yang dimaksud kelas menengah adalah orangorang yang berkesempatan mengenyam pendidikan tinggi, yang selanjutnya disebut kelas terdidik.

Kemunculan kelas terdidik yang mewakili To Pulo agak sulit dilacak titik berangkatnya, dan pada kurun tahun berapa pertama kali hadir, yang selanjutnya mewarnai perpolitikan di Kepulauan Selayar. Karena keterbatasan dalam pelacakan itu, setting pasca Orde Baru menjadi pilihan dalam studi ini untuk memulai menjelaskan tentang kelas terdidik To Pulo.

Aktivitas intens To Pulo di kota Makassar mulai terlihat tahun 2000-an. Sekalipun jumlah mereka sangat terbatas, di kemudian hari ternyata mereka memberikan andil yang cukup besar bagi kebangkitan ataua kemenangan To Pulo itu sendiri. Kebanyakan dari mereka adalah mahasiswa yang menempuh pendidikan di berbagai perguruan tinggi dan menghabiskan sebagian hidup mereka dalam kegiatan-kegiatan organisasi.
Pada awalnya mahasiswa To Pulo bergabung di bawah organisasi Gerakan Mahasiswa Pelajar Indonesia Tanadoang (GEMPITA) Selayar. Organisasi ini didirikan sejak tahun 1966 di kota Makassar, dengan tujuan menghimpun mahasiswa yang berasal dari kabupaten Kepulauan Selayar. Namun perkembangannya, mahasiswa To Pulo mendirikan organisasi sendiri tahun 2003 yang diberi nama Himpunan Pelajar Mahasiswa Kepulauan Selayar(HPMKS). Organisasi seperti ini biasanya dibentuk sebagai perwujudan dari komitmen sejumlah orang yang mempunyai kepedulian terhadap persoalan-persoalan yang dihadapinya (Gaffar, 2006: 201).

Realitas pembangunan di Kepulauan membuat kelas terdidik ini terusik, dan mempertanyakan keseriusan pemerintah daerah dalam upaya meningkatkan kehidupan yang layak dan akses yang lebih bagi masyarakat. ${ }^{2}$ Bersamaan dengan itu, peran GEMPITA sebagai aktor intermediary kembali dipertanyakan. Seberapa serius pengurusnya memperjuangkan nasib masyarakat Kep. Selayar, baik di kepulauan maupun di daratan. Pertanyaan yang terus menggantung, di sisi lain harapan bagi kehidupan yang lebih baik untuk masyarakat Kepulauan terus mendesak untuk segera terealisasi.

Berdirinya HPMKS adalah jawaban dari kegagalan GEMPITA dalam mengakomodasi kepentingan masyarakat Kepulauan, khususnya mahasiswa. Sebagaimana diungkapkan Nur Amin bahwa, "motivasi dasarnya adalah GEMPITA tidak bisa mengakomodir kepentingan masyarakat yang ada di pulau." Sebelum berdirinya HPMKS, mahasiswa To Pulo telah membangun komunikasi dengan tokoh-tokoh lokal yang mapan dan menetap di Makassar, yang menjadi pejabat penting di daerah Kep.Selayar setelah kemenangan Syahrir Wahab, sebagai orang To Pulo, dalam pilkada

\footnotetext{
${ }^{2}$ Wawancara dengan Hasimuddin, Oktober 2012
}

${ }^{3}$ Wawancara dengan Nur Amin, Oktober 2012 
langsung 2005. Walaupun tidak bisa dibuktikan relasinya, antara pendirian HPMKS dengan pencalonan Syahrir Wahab sebagai bupati, setidaknya memberikan perspektif baru pendirian HPMKS.

Selain isu pembangunan, kelas terdidik dengan diaspora To Pulo juga telah membicarakan masalah pemekaran kabupaten, denganisu adanya ketimpangan pembangunan. Mereka menghendaki kecamatan yang ada di kepulauan, misalnya kawasan TN. Taka Bonerate, agar berdiri sendiri dan mengelola keuangan dan administrasi secara mandiri sebagaimana Kab. Selayar (nama Kepulauan Selayar sebelum berganti nama), hal ini terjadi mengikuti tren beberapa daerah di Indonesia. Sejak runtuhnya Orde Baru, beberapa daerah di Indonesia menginginkan pemekaran dengan berbagai alasan, isu-isu primordial pun dijadikan pembenaran selain dari faktor kesenjangan pembangunan dan kesejahteraan.

Pada dekade awal reformasi, isu pemekaran memang sempat merebak. Bahkan penulis sendiri menyaksikan bagaimana Asri Muchtar kala itu, giat melakukan pertemuanpertemuan di Pulau Jampea dalam rangka membicarakan pemekaran. Dan disaat yang sama, diaspora To Pulo di Makassar juga mulai membicarakan kemungkinan-kemungkinan itu dan mempersiapkan infrastruktur kelembagaan yang dapat digunakan sebagai pressure groups. Kelompok inilah yang kemudian melahirkan HPMKS yang menaungi mahasiswa To Pulo.

Sekalipun dikatakan oleh Nur Amin bahwa pendirian HPMKS semata-mata antitesis dari ketidakbecusan GEMPITA memainkan perannnya sebagai aktor intermediary, tapi di sisi lain tidak bisa dikesampingkan bahwa pertemuan-pertemuan para diaspora ini juga ikut menentukan lahirnya lembaga tersebut. Masa depan pembangunan Kepulauan menjadi titik temu mereka untuk menyamakan visi politik, kemana Kepulauan akan diarahkan. Jika ditarik lebih jauh, lembaga To Pulo ini diharapkan menjadi kelompok penekan (pressure groups) bagi percepatan pembangunan di Kepulauan yang bermuara pada pemekaran.

Pertemuan yang intens ini melahirkan kesepakatan yang mereka sebut Komitmen Kepulauan yang isinya antara lain; 1 . Mendudukkan To Pulo sebagai Bupati Selayar; 2. Mendudukkan 8 kursi anggota DPRD Kabupaten yang berasal dari Kepulauan; 3. Membentuk Komite Percepatan Pembangunan; 4. Menghimbau masyarakat To Pulo untuk mengegolkan Syahrir Wahab sebagai bupati. ${ }^{4}$ Kini Syahrir Wahab menjadi bupati dua periode di Kepulauan Selayar (periode 2005-2010 dan 2010-2015).

Namun perkembangannya, isu pemekaran kembali redup. Ini bisa jadi diakibatkan karena konsentrasi mereka teralihkan kepada hal yang setidaknya akan menentukan masa depan mimpi mereka, yakni memenangkan pemilukada terlebih dahulu agar memudahkan pemekaran nantinya. Tapi lagi-lagi, kemenangan dipemilukada sama saja, tidak memberikan kontribusi yang berarti bagi penguatan isu pemekaran di kepulauan Selayar sampai dewasa ini. Bahkan perubahan nama kabupaten yang dulunya Kabupaten Selayar diganti menjadi Kabupaten Kepulauan Selayar berdasarkan PP No. 59/2008, menjadikan peluang dan usaha mereka menjadi sia-sia. Padahal To Pulo dari awal menggadang-gadang jika nantinya mereka dimekarkan akan menggunakan nama Kabupaten Kepulauan Selayar. Perubahan nama itu terjadi di bawah kepemimpinan Syahrir Wahab yang direpresentasikan sebagai To Pulo.

\section{Mobilisasi Identitas sebagai Gerakan Sosial}

Pemilahan antara To Pulo dan To Daratan sebagaimana disinggung pada bagian awal adalah konsep yang rancu. Distingsi ini muncul awalnya sebatas masalah geografis yang

\footnotetext{
${ }^{4}$ Wawancara dengan Nur Amin dan Hasimuddin, 2012
} 
merambah menjadi alat perjuangan politik, yang berkembang sampai sekarang dan memenuhi ruang diskursus politik di Kepulauan Selayar. Di pihak To Pulo, istilah ini di framing untuk memobilisasi dukungan yang berakar pada rasa primordialisme dan isu-isu kesenjangan. Dengan begitu, arah dukungan di lima kecamatan dapat ditarik ke dalam arus besar dan diarahkan untuk memenangkan kontestasi.

Jika dikaitkan dengan SIT terutama gagasan Touraine, identitas kolektif (sosial) cenderung direkonstruksi untuk mendefinisikan lawan dan kawan (Singh, 2010: 153). Namun pendefinisian ini keluar dari kerangka kelas dan lebih kepada siapa yang diserbu dan yang menyerbu. Melalui cara ini, solidaritas sebagai prasyarat untuk menguatkan gerakan dapat diciptakan. Artinya, formasi sosial yang ada dapat dimanipulasi dengan menghadirkan distingsi ke dalamnya. Sebelumnya, formasi sosial masyarakat Kepulauan Selayar tidak mengalami pembelahan semacam ini, To Pulo dan To Daratan. Namun, saat distingsi ini dihadirkan, maka formasi sosial berubah dan terkotakkan menjadi dua kubu.

To Pulo sepertinya sadar jika ingin memenangkan kontestasi dalam panggung politik lokal di Kepulauan Selayar, tidak ada jalan lain kecuali menciptakan identitas bersama bagi orang-orang di lima kecamatan sebagai To Pulo yang selama ini dianaktirikan dari segi pembangunan. Mengemukanya identitas kolektif To Pulo dengan embel-embel terbelakang dan termarjinalkan, akan membuat solidaritas masyarakat Kepulauan melekat kuat karena adanya persamaan nasib. Termarjinalkan dan terbelakang menjadi alat perekat. Hal inilah yang kemudian dijadikan sebagai piranti untuk memframing To Pulo sebagai suatu identitas kolektif. To Pulo secara teoretis tidak dapat digabungkan dalam analitis etnisitas karena realitanya mereka adalah kumpulan etnis yang dipersatukan atas nama satu nasib.

Semenjak pasca Orde Baru, pola ini sangat terlihat terutama saat dilangsungkannya pemilukada pertamadi KepulauanSelayartahun 2005, yang berperan penting menyuburkan isuisu To Pulo tidak lain adalah kelas menengah itu sendiri. Kalaupun sumber tersebut berasal dari elit-elit To Pulo, tapi operasionalnya tetap bertumpu pada kelas menengah.

Bukti konkret keterlibatan kelas menengah ini adalah mereka menjadi Tim Sukses kala itu, dan merekalah yang paling gencar menyuarakan isu-isu To Pulo. Sekalipun ditanggapi oleh para pendahulu HPMKS, keterlibatan mereka sebagai Tim Sukses untuk pasangan Syahrir Wahab-Syamsina Aroepala tahun 2005 bukan sebagai kerja-kerja lembaga melainkan kerja personal. Hampir semua pengurus terlibat aktif untuk mengampanyekan pasangan ini dengan jargon "To Pulo Harus Bersatu". Jargon ini tidak hanya berlaku dalam kontestasi pemilukada, akan tetapi juga muncul saat pemilihan umum legislatif.

Selain di ranah pemilukada dan legislatif, isu ini juga menguat di kalangan kelas terdidik, saat mereka bersaing memperebutkan posisi ketua GEMPITA. Pada tahun 2008 ketika diselenggarakan konferensi di Bantimurung, isu To Daratan-To Pulo menjadi hangat di kalangan mahasiswa Selayar pada saat itu. Para tokoh kunci mahasiswa paling mendorong isu ini, bahkan antarsenior ikut bersitegang dalam suksesi ketua umum. Senior-senior yang direpresentasikan sebagai To Daratan atau To Pulo mengambil posisi sesuai isu, mereka tidak berada pada posisi netral. Bahkan ketegangan itu terlihat pada pengambilan posisi dalam forum siding. Biasanya yang berasal dari daratan akan membentuk kelompok sendiri dan duduk di pojok ruangan, begitupun To Pulo. Konferensi Bantimurung berakhir deadlock dan dilanjutkan setelah dua minggu kemudian.

Satu tahun kemudian, mahasiswa To Pulo yang mayoritas menduduki ketua komisariat di GEMPITA menggulingkan ketua umum hasil kelanjutan konferensi Bantimurung, yaitu Saliding, yang juga merepresentasikan dirinya 
sebagai orang daratan. Kasus penggulingan ini juga pernah terjadi tahun 2002, Andi Lala sebagai ketua umum juga digulingkan. ${ }^{5}$ Sekalipun dalam kasus ini dibantah bahwa isu penggulingan bukan persoalan To Daratan - To Pulo.

\section{Disorientasi Politik: Ke mana Arah Politik Mereka?}

Ketika mimpi-mimpi masa lalu tentang pemekaran kini mengendap, menandakan visi politik kelas terdidik To Pulo dari awal tidak stabil. Hanya sebagian dari Komitmen Kepulauan yang bisa mereka tepati, terutama ketika meloloskan To Pulo menjadi bupati di Kepulauan Selayar. Tapi di saat yang sama, kelas terdidik ini tidak mampu mendesak pemerintah untuk mewujudkan mimpimimpi awal mereka. Padahal yang memegang kekuasaan adalah orang yang dianggap sebagai representatif To Pulo.

Sekalipun kini, sejak pemerintahan Syahrir Wahab sudah banyak To Pulo yang memegang kendali dalam pemerintahan, upaya ke arah pemekaran nyaris tidak kunjung terlihat. Beberapa penyebab yang melatarbelakanginya adalah pertama, gerakan politik identitas yang dilakukan sama sekali tidak ideologis dan mengakar, sehingga mudah rapuh. Perjuangan tuntutan ini terlihat tidak konsisten padahal peluang mereka terbuka lebar. Konsistensi sangatlah prinsipil dalam gerakan sosial, karena menentukan berhasil tidaknya tuntutan terpenuhi. Banyak gerakan sosial tidak mencapai klimaks, karena dirontokkan oleh ketidakmampuan mereka merawat konsistensi.

Kedua, kehendak politik dari kalangan elit To Pulo lemah karena energinya tergerus pada hal-hal pragmatis dan kepentingan sesaat, dalam percaturan politik lokal di Kepulauan Selayar. Padahal mereka memiliki kekuatan di DPRD ditambah beberapa To Pulo pada periode 2005-2014 banyak yang menjabat

${ }^{5}$ Wawancara dengan Hasimuddin, Oktober 2012 sebagai ketua partai. Di antaranya, PAN yang diketuai Abdul Gani, ia pernah terlibat dalam diskusi-diskusi di kalangan diaspora To Pulo di Makassar sehingga melahirkan komitmen kepulauan. PAN mendapat jatah lima kursi di DPRD pada periode 2009-2014. Sementara Demokrat diketuai oleh Sukran Yusuf, yang juga duduk sebagai anggota DPRD. Demokrat memiliki dua kursi di DPRD periode 20092014. Begitupun PKB juga diketuai To Pulo, yakni Zainuddin Dg. Mattola. Belum lagi Partai Golkar yang menjadi mayoritas di DPRD, diketuai To Pulo yaitu Syahrir Wahab. Meskipun begitu, tidak ada usaha ke arah mobilisasi dukungan untuk mencapai mimpimimpi mereka di masa lalu.

Ketiga, perubahan sosial dan penetrasi dalam menyuarakan isu-isu pemekaran diharapkan datang dari kelas menengah, ternyata juga lemah. Padahal mereka juga memegang posisi kunci dalam beberapa organisasi. Misalnya, GEMPITA sebagai organisasi induk mahasiswa Kepulauan Selayar, telah dimenangkan oleh mahasiswa To Pulo, yang belum pernah dimenangkan setelah sekian lama. Belum lagi organisasiorganisasi ekstra yang memiliki cabang di Kepulauan Selayar, seperti IMM dan HMI juga dikendalikan oleh To Pulo.

Kendala utama yang dihadapi kelas menengah atau terdidik ini adalah mereka disibukkan oleh konflik internal lembaga. Contohnya, GEMPITA masih sibuk mempersoalkan persaingan antara To Pulo vs To Daratan dan HPMKS disibukkan mencari resolusi konflik yang melanda lembaga mereka. Sesama mahasiswa To Pulo saling berhadap-hadapan karena merasakan ketidakadilan bagi mahasiswa di luar Kec. Pasimasunggu, Pasimasunggu Timur, dan Taka Bonerate yang memonopoli struktur kepengurusan di dalamnya. Bagi mahasiswa Kec. Pasilambena dan Pasimarannu. HPMKS tidak ubahnya organisasi tiga kecamatan, padahal tujuan didirikannya adalah untuk 
menghimpun mahasiswa lima kecamatan yang ada di kepulauan. Namun baru-baru ini, kepemimpinan HPMKS sudah dipegang oleh mahasiswa dari Kec. Pasilambena.

Di sisi lain, kinerja organisasi kelas terdidik cenderung didikte oleh kekuatan politik elit, sehingga mereka tidak leluasa melakukan manuver gerakan untuk menyuarakan isu-isu kepulauan secara umum danjuga isu pemekaran. Hal ini bermula ketika para pendahulu atau senior merambah jalur politik praktis. Banyak dari mereka terlibat dalam partai politik dan bergabung dengan faksi-faksi politik yang ada di Kep. Selayar. Belum lagi ketergantungan finansial untuk mendanai kegiatan, mereka lebih banyak bergantung pada kantong-kantong elit dan senior. Tidak mengherankan jika aktivitas kelas terdidik ini bergantung pada gerak bandul elit dan senior mereka.

Keempat, selain mandeknya kelas terdidik dalam peran sebagai aktor intermediary, para pendahulu mereka pun tidak berhasil mentransmisikan ide-ide pemekaran ke generasi sekarang. Hal ini tentu berkaitan dengan bagian pertama, bahwa watak dari gerakan politik identitas yang mereka lakukan sebatas mengonsolidasikan secara internal untuk mendapatkan dukungan politik di kala kontestasi berlangsung, seperti pemilukada.

Secara teoretis, melemahnya atau disorientasi gerakan sosial To Pulo terletak pada persoalan komitmen. Sekalipun telah mampu menciptakan identitas kolektif dan bisa memobilisasi identitas dalam setiap kontestasi, sayangnya komitmen mereka lemah. Padahal komitmen untuk mencapai tujuan tersebut menjadi prasyarat berhasil tidaknya gerakan sosial. Pada akhirnya, visi politik mereka tentang pemekaran jadi mengambang, tergantikan oleh kepentingan-kepentingan pragmatis yang sifatnya sesaat. Hal ini ditandai oleh tidak adanya usaha serius dari To Pulo untuk mewujudkan cita-cita mereka, dan dikunci dengan perubahan nama dari Kab. Selayar menjadi Kab. Kepulauan Selayar. Hal ini justru terjadi di masa kepemimpinan To Pulo. Padahal mereka bercita-cita ingin memekarkan lima kecamatan di kawasan Taman Nasional Taka Bonerate menjadi kabupaten dengan menggunakan nama Kepulauan Selayar.

\section{Melemahnya Peran Intermediary To Pulo}

Selain kaburnya orientasi perjuangan kelas menengah To Pulo lantaran lemahnya komitmen mereka, peran mereka sebagai aktor intermediary juga mengalami kemerosotan. HPMKS sebagai perkumpulan kelas menengah dan terdidik, pada perkembangannya semakin keluar dari aktivitas-aktivitas penguatan masyarakat sipil (civil society) dan peranan untuk mengawal pembangunan di Kepulauan. Mereka justru terjebak dalam aktivitas politik yang berbasiskan isu identitas primordial. HPMKS kemudian menjadi bagian dari menguatnya wacana identitas primordial itu. Identitas kultural telah masuk dalam kehidupan kelas terdidik dan berhasil dilembagakan. Secara bersamaan, HPMKS sekaligus menjadi simbol kekuatan kelas terdidik dari Kepulauan dan mengambil tempat dalam perpolitikan di Kepulauan Selayar.

Anggota HPMKS secara nyata terlibat dalam suksesi pemilihan kepala daerah pertama di Kabupaten Kepulauan Selayar tahun 2005. Baik Hasimuddin maupun Nur Amin mengakui bahwa keterlibatan mereka bukan atas nama lembaga, namun menjadi dilematis untuk memisahkan aktivitas personal dengan aktivitas kelembagaan. Anggota HPMKS kebanyakan menjadi tim sukses untuk pasangan Syahrir Wahab dan Syamsina Aroepala yang mengusung tagline "Orang Pulau Harus Bersatu" saat kampanye di lima kecamatan Kepulauan. Sekalipun tagline ini tidak resmi digunakan di tingkat kabupaten, namun lebih sering disuarakan ketika melakukan kampanye di daerah Kepulauan. Syahrir Wahab sendiri adalah To Pulo pertama yang maju dan berhasil merebut jabatan Kepala Daerah di Kabupaten Kepulauan Selayar. 
Sebagai aktor intermediary, kelas terdidik ini kemudian mengalami kemerosotan daya kritis. Suara-suara kritis mereka di awal tahun 2000-an mengenai kesejahteraan dan pembangunan di Kepulauan kini tidak terdengar lagi. Terdapat tiga penjelasan untuk konteks ini; pertama, hilangnya suara kritis tersebut tidak lepas dari kemenangan Syahrir Wahab, To Pulo pertaman yang menjabat sebagai Bupati Kepulauan Selayar. Mengkritisi kebijakan pemerintah daerah sama saja mempermalukan Syahrir Wahab dan To Pulo itu sendiri.

Kedua, HPMKS sebagai media berkreasi, secara finansial tidak mandiri. Lembaga ini lebih banyak mendapatkan bantuan dari pemerintah daerah. Sekalipun tidak terdaftar sebagai organisasi resmi sebagaimana GEMPITA, namun HPMKS menikmati APBD Kepulauan Selayar untuk mendanai program kerja. Suara kritis mereka menghilang karena ketergantungan yang lebih besar terhadap Syahrir Wahab, sebagai pemegang otoritas di Kepulauan Selayar.

Ketiga, sebagian dari penggagas HPMKS telah bergabung dengan partai politik, dan sebagiannya lagi menjadi PNS di Kepualaun Selayar. Pengurus HPMKS saat ini lebih banyak bergantung pada senior, karena kemampuan mereka melobi pencairan anggaran dan sebagainya sangat lemah. Dilematis, mengingat relasi yang terbangun antara bupati dan penggagas HPMKS, baik yang PNS maupun anggota partai saling berkepentingan, yang menyebabkan daya kritis semakin surut dan hilang.

Secara umum HPMKS yang lahir dari rahim To Pulo, perkembangannya sangat menghawatirkan. Peran sebagai aktor intermediary sama sekali tidak terlihat. Padahal latar belakang berdirinya berangkat dari keprihatinan atas kondisi kepulauan, karena itu dibutuhkan kerja-kerja intermediary untuk mewujudkan visi awal mereka. Dilematis memang, di satu sisi, mengkritik Syahrir
Wahab atas pembangunan di kepulauan sama saja mempermalukan To Pulo, namun di sisi lain kinerja dan upaya pembangunan di kepulauan juga membutuhkan kritik yang membangun dari mereka.

Persoalan pembangunan luput dari perhatian. Misalnya, pembangunan jalan lingkar di Pulau Jampea yang tidak beres dan pembangunan bandara yang salah sasaran di kawasan Taman Nasional Taka Bonerate (Sindonews.com, 2013; kabarsulawesi.com, 2014). Kekhawatiran Hadiwinata (2005) terbukti, yaitu aktor intermediary dapat saja keluar dari agenda mereka manakala tidak bersifat mandiri. Pendanaan HPMKS tergantung pada senior dan elit To Pulo, sementara para elit dan senior mempunyai kepentingan dan posisi dalam struktur pemerintahan di Kepulauan Selayar. Kondisi tersebut menyebabkan mereka sulit mengawal dan mengkritisi kebijakan pemerintah di Kepulauan.

\section{Kesimpulan}

Gerakan sosial To Pulo merupakan gerakan sosial yang berbasis identitas. To Pulo sebagai identitas kolektif diciptakan untuk menyolidkan masyarakat lima kecamatan di Kepulauan demi perjuangan politik. Melalui framing, keterbelakangan dan kesenjangan pembangunan dibingkai sebagai alasan untuk menyatukan etnis yang berserak ini menjadi satu entitas yaitu To Pulo.

Tujuan awal gerakan ini adalah tuntutan akan akselerasi pembangunan dan pemekaran wilayah, sehingga mereka merekonstruksi identitas kolektif sebagai To Pulo agar dapat dimobilisasi dalam panggung politik. Setelah berhasil memenangkan kontestasi Pemilukada 2005, beberapa dari mereka menduduki posisi penting dalam pemerintahan, sayangnya tuntutan akan pemekaran wilayah justru tidak terdengar lagi. Hal ini disebabkan oleh lemahnya komitmen mereka terhadap tujuan awal, padahal komitmen untuk perjuangan sangat fundamental bagi suksesnya gerakan 
sosial (Sukmana, 2013). Disorientasi ini ditandai dengan hilangnya diskursus pemekaran di kalangan To Pulo, ditambah lagi tidak adanya kehendak politik elit To Pulo.

Terjadinya disorientasi disebabakan oleh; pertama, tidak adanya komitmen kuat dari To Pulo untuk melanjutkan perjuangan bagi pemekaran dan akselerasi pembangunan di Kepulauan; kedua, gerakan sosial berbasis identitas yang mereka lakukan sama sekali tidak ideologis dan mengakar, sehingga mudah rapuh; ketiga, kehendak politik dari kalangan elit To Pulo lemah karenak energy yang tergerus pada hal-hal pragmatis dan kepentingan sesaat, dalam percaturan politik lokal di Kepulauan Selayar; keempat, gagalnya para pendahulu mereka dalam mentransmisikan ide-ide pemekaran kepada kelas menengah To Pulo saat ini.

Di samping terjadinya disorientasi gerakan sosial To Pulo, kelas mengah sebagai aktor intermediary mengalami kemunduran. Hal ini disebabkan oleh konflik internal yang terjadi sehingga energinya dihabiskan untuk mencari resolusi konflik. Selain itu, HPMKS sebagai instrumen perjuangan politik kelas menengah ini, dari segi finansial tidak mandiri sehingga mudah didikte oleh kekuatan luar. Peran mereka justru memperparah perkembangan politik aliran atau identitas di Kepulauan Selayar. Merekalah yang aktif menyuarakan distingsi dan memobilisasi identitas ke dalam panggung politik dewasa ini. Namun, politik aliran ini tidak diarahkan pada pencapain visi politik mereka seperti di awal pasca Orde Baru.

\section{Daftar Pustaka}

Abdilah, U. (2002). Politik Identitas Etnis: Pergulatan Tanda Tanpa Identitas. Magelang: IndonesiaTera.

Aziz, A. (2008). Memahami Fenomena Sosial Melalui Studi Kasus. Analisis Data Penelitian Kualitatif: Pemahaman filosofis dan Metodologis ke Arah Penguasaan Model Aplikasi. Jakarta: Rajawali Pers.
Davidson, J.S; D. Henley, S; Moniaga. (Eds)/2010. Adat dalam Politik Indonesia. Jakarta: Yayasan Obor Indonesia \& KITLV-Jakarta.

Dick, H. W. (1985). The Rise of a Middle Class and the Changing Concept of Equity in Indonesia: an Interpretation. Indonesia. Vol. 39 April 1985. Pp. 71-92.

Gaffar, A. (2006). Politik Indonesia: Transisi Menuju Demokrasi. Yogyakarta: Pustaka Pelajar.

Haboddin, M. (2012). Menguatnya Politik Identitas di Ranah Lokal. Jurnal Studi Pemerintahan. Vol. 3 No. 1 Februari 2012. Pp.109-126.

Hadiwinata, B.S. (2005). Civil Society: Pembangun dan Sekaligus Perusak Demokrasi. Jurnal Ilmu Sosial dan Ilmu Politik. Vol. 9 No. 1 Nopember 2005. Pp. 1-22.

Hall, S. (1996). Introduction: Who Needs 'Identity'?. Question of Cultural Identity. London: Sage Publication.

Haryanto; Hairini, Siti Mauliana; Bakar, Abu. (2013). PKBI: Aktor Intermediary dan Gerakan Sosial Baru. Jurnal Ilmu Sosial dan Ilmu Politik. Vol. 16 No. 3 Maret 2013. Pp. 187-199.

Jaya, H. (Ed)/1999. Kelas Menengah Bukan Ratu Adil. Yogyakarta: Tiara Wacana.

Klinken, G. v. (2007). Perang Kota Kecil: Kekerasan Komunal dan Demokratisasi di Indonesia. Jakarta: Yayasan Obor Indonesia \& KITLV-Jakarta.

Nordholt, H.S \& Klinken, G. v. (Eds)/2007. Politik Lokal di Indonesia. Jakarta: Yayasan Obor Indonesia \& KITLV-Jakarta.

Tanasaldy, T. (2007). Politik Identitas Etnis di Kalimantan Barat. Dalam Nordholt, H.S \& Klinken, G. v. (Eds). Politik Lokal di Indonesia. Jakarta: Yayasan Obor Indonesia \& KITLVJakarta.

Mackie, J. A. C. (1984). Harta dan Kuasa dalam Orde Baru di Indonesia. Prisma. Vol. 13 No. 2 Februari 1984. Pp. 30-46.

Ramstedt, M. \& Thufail, F. I. (Eds)/ 2011. Kegalauan Identitas: Agama, Etnisitas dan Kewarganegaraan pada Masa Pasca-Orde Baru. Jakarta: Grasindo. 
Singh, R. (2010). Gerakan Sosial Baru. Yogyakarta: Resist Book.

Subianto, B. (1999). Kelas Menengah Indonesia: Konsep yang Kabur. Dalam H. Jaya (Ed). Kelas Menengah Bukan Ratu Adil. Yogyakarta: Tiara Wacana.

Suharko (2006). Gerakan Sosial Baru di Indonesia: Repertoar Gerakan Petani. Jurnal Ilmu Sosial dan Ilmu Politik. Vol. 10 No. 1 Juli 2006. Pp. 1-34.

Sukmana, O. (2013). Konvergensi Antara Resource Mobilization Theory dan Identity Oriented Theory dalam Studi Gerakan Sosial Baru. Sosiologi Reflektif. Vol. 8 No. 1 Oktober 2013. Pp. 39-62.

Tanter, R. \& Young, K. (Eds)/1993. Politik Kelas Menengah Indonesia. Yogyakarta: LP3ES.
Yin, R. K. (2005). Studi Kasus: Desain dan Metode. Jakarta: Raja Grafindo Persada.

Amir, Herni. (2013). Pemindahan Bandara di Selayar Ancam Seret Pejabat. (Online). (http:// daerah.sindonews.com/read/756103/25/ pemindahan-bandara-di-selayar-ancamseret-pejabat-1372671902, diakses tanggal 3 Februari 2015).

Syarif, Fadli. (2014). Desak Pemakzulan, Bupati Selayar Diduga Korupsi Dana APBD. (Online). (http://www.kabarsulawesi. com/2014/04/desak-pemakzulan-bupatiselayar-diduga.html, diakses tanggal 3 Februari 2015).

\section{Wawancara}

Hasimuddin, Oktober 2012.

Nur Amin, bulan Oktober 2012. 